\title{
KETERAMPILAN NARASI SISWA TULI PADA TINGKAT MIKRO
}

\author{
Alies Poetri Lintangsari ${ }^{1} \quad$ Wahyu Widodo ${ }^{2} \quad$ Rachmawati Ayu Kuswoyo ${ }^{3}$ \\ Universitas Brawijaya ${ }^{l, 2,3}$ \\ alieslintang@ub.ac.id ${ }^{1}$
}

\begin{abstract}
Abstrak
Penelitian ini bertujuan untuk mengetahui keterampilan anak-anak Tuli di tataran penulisan narasi. Subjek penelitian ini adalah 37 siswa kelas 1 sampai kelas 6 Sekolah Dasar Luar Biasa Yayasan Pendidikan Tunas Bangsa (SDLB YPTB) Malang. Penelitian kualitatif ini menggunakan dua instrumen, yaitu (1) film bisu berdurasi enam menit The Pear Story 'Kisah Buah Pir' yang digunakan untuk memancing subjek menarasikan apa yang telah dilihat dan kemudian menuliskan film tersebut dalam bentuk narasi, (2) narrative scoring guidelines 'panduan penilaian narasi' yang mengukur keterampilan narasi pada tingkat mikro struktur yang meliputi kohesi naratif, kohesi referensial, penggunaan konjungsi, pembentukan kata-kata gramatikal, dan piranti-piranti naratif.
\end{abstract}

Kata kunci: Tuli, keterampilan menulis, narasi, tingkat mikro

\begin{abstract}
This study aims to find out the narrative skills in deaf children. The participants in this research are 37 children from grade 1 to 6 from Sekolah Dasar Luar Biasa Yayasan Pendidikan Tunas Bangsa (SDLB YPTB) in Malang. This qualitative research uses two instruments: (10 The Pear Story, a six-minute silent movie to elicit the narrative story, and (2) narrative scoring guidelines to measure the narrative skills in the micro-structure which involves narrative cohesion, referential cohesion, the use of conjunctions, the formation of grammatical words, and the use of narrative devices.
\end{abstract}

Keywords: Deaf, writing competence, narration, micro level

\section{PENDAHULUAN}

Sejak tahun 2012, Universitas Brawijaya telah menerima penyandang disabilitas melalui program SPKPD (Seleksi Penerimaan Khusus Penyandang Disabilitas) dan PSLD (Pusat Studi dan Layanan Disabilitas) dengan memberikan layanan khusus bagi mahasiswa penyandang disabilitas. Total mahasiswa penyandang disabilitas yang menempuh pendidikan tinggi di Universitas Brawijaya berjumlah 80 orang dengan berbagai macam jenis disabilitas. Dari 80 orang peserta didik, 43 di antaranya adalah mahasiswa Tuli. Dari jumlah total mahasiswa Tuli, sebagian besar di antaranya memiliki kemampuan literasi yang rendah. Dalam ranah morfologi, misalnya, mereka kesulitan menggunakan morfem infleksi dan derivasi, sedangkan dalam ranah sintaksis, baik di tingkat frasa maupun kalimat, mereka cenderung menggunakan pola inversi. Selain tataran morfologi dan sintaksis, mereka juga mengalami kesulitan di ranah semantik, khususnya pemahaman leksem berkonsep abstrak dan emosi. Pemaparan di atas memantik pertanyaan utama bagaimanakah sejatinya pembelajaran membaca dan menulis diajarkan di tingkat sekolah dasar bagi anak-anak Tuli? Apakah kecakapan literasi yang rendah dan lemah di tingkat perguruan tinggi tersebut bermuasal dari pembelajaran di tingkat sekolah dasar? 
Jawaban dari pertanyaan tersebut berkaitan dengan tujuan utama penelitian ini, yaitu bagaimanakah kecakapan menulis narasi bagi anak Tuli di tingkat sekolah dasar?

Kecakapan narasi dipilih karena di dalam teks narasi memuat kecakapan bahasa yang kompleks meliputi perbendaharaan kosakata, kemampuan menggunakan kata dalam konteks yang tepat, kemampuan menyusun kalimat, kecakapan menyusun struktur naratif, dan kemampuan mengawetkan pengalaman pribadi. Ada tiga hal yang berperan dalam proses produksi teks narasi dalam ranah kognitif anak, yaitu (1) piranti bahasa, yang di dalamnya memerinci keterkaitan babak demi babak, (2) kemampuan pragmatik, yang di dalamnya memuat kesadaran siapa saja yang terlibat dalam percakapan, baik penutur maupun mitra tutur, dan (3) pelibatan kerja memori dalam artian anak yang menulis teks narasi dalam ranah kognisinya dipacu keras untuk mengingat kembali dan menuliskannya sehingga ada proses pengawetan ingatan (Rathmann, Mann, \& Morgan, 2007). Berdasarkan peran teks narasi dalam proses perkembangan kognitif anak, penelitian ini bertujuan untuk mengetahui seberapa jauh proses pemahaman dan keterampilan siswa Tuli dalam menulis narasi yang kemudian akan menuntun pada kajian yang lebih spesifik dalam penelitian ini didasarkan pada kajian, yaitu kajian struktur mikro, pada tataran ini, penelitian ini akan mengungkap keterampilan menulis dan pemahaman koherensi, tata bahasa serta perbendaharaan kata siswa Tuli.

Partisipan penelitian ini adalah siswa Tuli di tingkat sekolah dasar kelas 1 dan 6 sejumlah 37 orang siswa dari Sekolah Dasar Luar Biasa Yayasan Pendidikan Tunas Bangsa (SDLB YPTB) (khusus siswa Tuli) di kota Malang. Sebagai piranti untuk mengumpulkan data digunakan film bisu yang berjudul The Pear Story dalam durasi enam menit. Film tersebut dibuat oleh Wallace Chafe, seorang ahli linguistik Amerika pada tahun 1985 yang digunakan untuk memperoleh cerita narasi dari berbagai pembicara dengan latar belakang bahasa dan budaya yang berbeda di seluruh dunia (Sukamto \& Purwo, 2016). Analisis data pada tataranmikro yang meliputi kohesi leksikal (cohesion), proses pembentukan gramatika (grammatical morphemes), kohesi dan evaluasi penceritaan (narrative and evaluative cohesion) (Jones dkk., 2016).

\section{WACANA NARATIF DAN PERKEMBANGAN BAHASA KEDUA}

Bab ini memaparkan tentang wacana naratif yang merujuk pada teks naratif dan 'wacana' yang merujuk pada tingkat analitik struktur bahasa, yang termasuk didalamnya keberlindangan beberapa ujaran yang membentuk rangkaian kalimat. Wacana naratif terdiri dari beberapa lapis informasi tentang karakter, tempat dan kejadian. Dalam memproduksi wacana naratif, seseorang akan melibatkan tiga bidang kognisi, yaitu (Rathmann dkk., 2007):

1. Piranti-piranti linguistik yang digunakan dalam merangkai kalimat sehingga membentuk wacana yang lebih luas termasuk babak dan keadaan (setting).

2. Kemampuan pragmatik merupakan hal terpenting dalam produksi dan pemahaman wacana naratif, termasuk keawasan dalam memahami percakapan dan informasi yang dibutuhkan.

3. Kemampuan kognisi umum yang termasuk dalam naratif, contohnya proses pengawetan ingatan dan informasi dalam memproses peruntunan informasi

Menilik proses produksi wacana naratif yang melibatkan tiga bidang kognisi sebagaimana dipaparkan di atas, beberapa teori mengungkapkan bahwa keterampilan naratif 
dapat mempengaruhi perkembangan bahasa seseorang, baik lisan maupun tulis. Komponenkomponen naratif dapat meningkatkan perkembangan bahasa kedua karena pengolahan wacana naratif tidak hanya berpengaruh pada kompetensi komunikatif seseorang namun juga meningkatkankannya karena dalam proses mengolah wacana naratif, seseorang tidak hanya menyusun makna bagi dirinya sendiri namun juga bagi orang lain sehingga dapat meningkatkan kompetensi komunikatif seseorang (Negueruela, 2008). Komponen naratif (Pavlenko \& Lantolf, 2000) terdiri dari struktur, evaluasi, elaborasi dan kohesi. Komponen pertama adalah pengetahuan terhadap struktur komponen naratif dalam bahasa sasaran and kemampuan untuk menggunakanya secara baik dan sesuai dalam konteks. Beberapa studi tentang penguasaan naratif pembelajar bahasa kedua sangat dipengaruhi oleh struktur naratif bahasa pertama mereka. Jika struktur naratif bahasa pertama memiliki struktur naratif yang sama dengan bahasa kedua, maka pembelajar akan lebih mudah dalam memahami dan memproduksi wacana naratif dalam bahasa kedua.

Komponen kedua adalah evaluasi dan elaborasi. Dalam mengelaborasi wacana naratif, seseorang akan menggunakan leksem, bahasa kiasan, reported speech, perumpamaan, dan deskripsi. Dalam mengevaluasi wacana naratif, seseorang berusaha untuk menyampaikan inti dari sebuah cerita dengan menggunakan intensifier, modal verbs, negatives, pengulangan, komentar evaluatif, embedded speech, dan perbandingan dengan kisah kiasan (Labov, 1972).

Komponen yang ketiga adalah kohesi naratif, yakni sebuah makna semantik yang merujuk pada hubungan makna dan teks, yang secara garis besar dibagi menjadi dua yaitu kohesi gramatikal (referen, substitusi, elipsis, dan konjungsi) dan kohesi leksikal (reiterasi dan kolokasi). Dalam penyusunan wacana naratif, seseorang akan menggunakan komponen kohesi naratif sehingga dapat meningkatkan dan memperkaya keterampilan bahasa kedua seseorang. Keterampilan menyusun wacana naratif berkontribusi dalam perkembangan bahasa dan komunikasi seseorang. Maka dari itu, keterampilan naratif sangatlah penting untuk meningkatkan keterampilan literasi dan performa akademik seseorang.

Dari penjelasan tersebut, dapat dipahami bahwa komponen-komponen dalam wacana naratif sangat potensial untuk meningkatkan kemampuan dan/atau keterampilan bahasa kedua seseorang. Lalu bagaimana dengan anak Tuli? Bagaimana hubungan wacana naratif dengan keterampilan berbahasa anak Tuli? Bagian selanjutnya akan memaparkan tentang penelitianpenelitian terdahulu yang membahas tentang hubungan naratif dengan keterampilan berbahasa anak Tuli.

\section{PRODUKSI NARATIF PADA ANAK TULI}

Tuli adalah kondisi dimana seseorang memiliki keterbatasan pendengaran yang menghambat stimuli audio sensori sehingga berakibat pada kemampuan berbicara. Kondisi ini mendorong adanya normalisasi dengan merepresentasi kaidah Bahasa Indonesia Lisan menjadi Sistem Bahasa Isyarat Indonesia (SIBI). Hal ini bermula dari pandangan yang melihat orang Tuli sebagai orang cacat (Tunarungu) sehingga tindakan yang diberikan adalah tindakan rehabilitasi dalam bentuk terapi wicara dan normalisasi bahasa Isyarat. Dalam pandangan sosial budaya, Tuli merupakan identitas kebahasaan yaitu bahasa Isyarat. Melalui pendekatan sosial budaya, ketulian tidak dipandang sebagai kecacatan, namun dipandang sebagai potensi budaya yang melahirkan identitas kebahasaan yaitu bahasa Isyarat. Pendekatan sosial budaya melihat Tuli sebagai masyarakat dengan kemampuan berbahasa yang berbeda, sehingga kedudukan bahasa 
Isyarat bagi masyarakat Tuli tidak hanya sebagai media komunikasi namun sebagai identitas linguistik masyarakat Tuli. Dalam artikel ini, peneliti menggunakan istilah Tuli (bukan Tunarungu) berdasarkan dua pertimbangan, yaitu (1) istilah Tuli merupakan preferensi sebagian besar Komunitas Tuli, dan (2) peneliti menggunakan pendekatan sosial budaya. Berbagai penelitian sebelumnya mengungkapkan bahwa secara umum individu Tuli mengalami hambatan dalam hal literasi khususnya dalam hal penggunaan piranti linguistik, keterbatasan penguasaan kosakata dan produksi kalimat yang cenderung sederhana (Schley \& Albertini, 2005).

Penelitian kemampuan menulis narasi siswa Tuli pada tingkat sekolah dasar didasarkan pada bagaimana teks narasi diproduksi oleh siswa Tuli. Sebagian besar anak Tuli menggunakan bahasa isyarat, baik bahasa isyarat rumah (home sign) maupun bahasa isyarat umum (SIBI atau BISINDO). Dalam proses penulisan narasi bagi anak Tuli di dalamnya ada perpindahan dari bahasa isyarat ke tulisan, sedangkan bagi anak-dengar ada perpindahan dari lisan ke tulisan (Rathmann dkk., 2007). Ada tiga hal yang berperan dalam produksi teks narasi dalam ranah kognitif anak (1) piranti bahasa, yang di dalamnya merinci keterkaitan babak demi babak, (2) kemampuan pragmatik, yang di dalamnya memuat kesadaran siapa saja yang terlibat dalam percakapan, baik penutur maupun mitra tutur, dan (3) pelibatan kerja memori dalam artian anak yang menulis teks narasi dalam ranah kognisinya dipacu keras untuk mengingat kembali dan menuliskannya sehingga ada proses pengawetan ingatan (Rathmann dkk., 2007). Kaitannya dalam penelitian ini, penelitian ini menyasar keterampilan siswa Tuli dalam tataran-mikro untuk melihat piranti bahasa dan pragmatik.

Produksi naratif melibatkan kemampuan mengungkapkan cerita yang menuntut keterampilan bahasa dan kognitif dalam tingkat mahir. Keterampilan ini termasuk keterampilan dalam merangkai babak, menciptakan teks yang koheren dengan piranti-piranti linguistik, pemilihan kosakata yang tepat, untuk mengungkapkan ide, untuk memahami efek sebab-akibat, dan untuk menyusun keseluruhan cerita.

Apabila seseorang mengalami kesulitan dalam menyusun wacana naratif, hal tersebut tidak hanya disebabkan oleh kelemahan dalam tingkat morfologi dan sintaksis, namun merupakan kelemahan dalam memproses kode, menyusun, dan menghubungkan proposisi serta kesulitan dalam mensarikan kembali makna kata yang berbeda dengan tepat (Bernaix, 2013).

Produksi naratif pada anak Tuli menunjukkan adanya hambatan dalam perkembangan bahasa, hal ini diduga disebabkan karena anak Tuli tidak memiliki skemata cerita yang memadai sehingga anak Tuli tidak dapat menyusun materi yang ia dapatkan. Hal ini dimungkinkan karena anak Tuli lemah dalam memproses kode, menyusun serta menghubungkan proposisi sehingga mengalami kesulitan dalam penyusunan skemata cerita. Kesulitan tersebut dapat disebabkan karena beberapa faktor antara lain perbedaan karakterstik bahasa pertama dan bahasa kedua, sebagaimana diketahui bahwa bahasa pertama anak Tuli adalah bahasa visual yang memiliki karakter gramatikal yang berbeda dengan bahasa tulis. Faktor yang kedua adalah kurangnya penguasaan kosakata anak Tuli. Faktor yang ketiga adalah keterbatasan mereka dalam mendengar, karena pada anak Dengar, proses identifikasi kata tertulis dengan cara membunyikan kata-kata tersebut dalam hati untuk dapat lebih memaknai maknanya, sehingga terdapat proses kodifikasi dari fragmen visual menjadi fragmen bunyi. Proses ini yang kemudian membantu anak Dengar untuk lebih memahami makna sebuah cerita. Dengan hilangnya indra pendengaran, anak Tuli tidak mengalami proses ini. Adanya beberapa hambatan yang dialami anak Tuli dalam penguasaan bahasa membuat anak Tuli mengalami keterlambatan dalam berbahasa, sebagaimana dipaparkan dalam penelitian sebelumnya bahwa keterampilan 
berbahasa anak Tuli yang berumur tujuh tahun hampir setara dengan keterampilan berbahasa anak Dengar yang berumur empat tahun (Bernaix, 2013).

Beberapa penelitian terdahulu yang berhubungan dengan penelitian ini adalah penelitian yang dilakukan oleh Jones dkk. (2016) yang berfokus pada keterampilan menulis narasi anakanak Tuli yang menggunakan bahasa Inggris lisan. Subjek dari penelitian tersebut adalah anakanak Tuli dan anak-anak Dengar yang berusia 6-11 tahun yang menggunakan Bahasa Inggris lisan. Data naratif didapatkan dari video yang dipertontonkan kepada subjek penelitian. Hasil penelitian menunjukkan bahwa anak-anak Tuli dan anak-anak Dengar memiliki kemampuan yang sama pada tingkat makro struktur, namun anak-anak Tuli memiliki kemampuan yang lebih rendah daripada anak-anak Dengar pada tingkat mikro struktur.

Penelitian serupa juga dilakukan di Amerika dengan partisipan anak Tuli yang menggunakan American Sign Language (ASL). Hasil penelitian menunjukkan bahwa kemampuan dasar membaca berperan signifikan terhadap kemahiran menulis dengan sarana tulis maupun mengembangkan bahasa isyarat pada tingkat lanjut. Penelitian itu menyarankan bahwa kemampuan membaca yang baik adalah prasyarat mutlak bagi anak Tuli (Chamberlain \& Mayberry, 2008).

Penelitian serupa juga dilakukan oleh Sukamto \& Purwo (2016) yang menggunakan instrumen yang sama dengan penelitian ini namun berfokus pada kelancaran naratif lisan dan tulis pada anak dengar dwibahasa di tingkat sekolah dasar. Hasil penelitian mereka mengungkapkan bahwa mereka lebih lancar bercerita dengan menggunakan bahasa pertama mereka yaitu bahasa Jawa daripada ketika menggunakan bahasa kedua mereka yaitu bahasa Indonesia.

\section{METODOLOGI}

Partisipan dalam penelitian ini merupakan siswa Tuli kelas 1 s.d. 6 dengan jumlah total 37 siswa dari Sekolah Dasar Luar Biasa Yayasan Pendidikan Tunas Bangsa (SDLB YPTB). Tahapan penelitian terdiri atas (1) penyusunan instrumen penelitian, (2) pengumpulan data, dan (3) analisis data. Dalam tahap penyusunan instrumen, peneliti menggunakan tiga instrumen, yaitu film bisu berjudul kisah buah pir (The Pear Story) sebagai media untuk memancing anak-anak menulis narasi, struktur narasi film bisu kisah buah pir (The Pear Story) yang diadaptasi dari Sukamto \& Purwo (2016), dan rubrik penilaian narasi dalam tingkat makro dan mikro yang diadaptasi dari Jones, dkk (2016). Analisis data dilakukan melalui dua tahapan: (1) menilai narasi siswa dengan menggunakan rubrik yang telah disiapkan. Penilaian ini digunakan untuk mengukur keterampilan narasi tingkat mikro dan (2) menganalisis data secara deskriptif dengan mempertimbangkan data kuantitatif dari hasil penilaian.

\section{PEMBAHASAN}

Dalam keterampilan narasi anak Tuli pada tingkat mikro, penilaian difokuskan pada empat indikator, yaitu kohesi naratif/referensial, penggunaan konjungsi, pembentukan kata-kata gramatikal, dan piranti-piranti naratif.

Nilai kohesi naratif/referensial mengacu pada penjelasan terkait identifikasi tokoh-tokoh yang dikisahkan. Poin ini didasarkan pada jumlah penyebutan identifikasi tokoh sesuai dengan kisah buah pir, yaitu ada tujuh tokoh. Sebanyak 2 poin diberikan untuk masing-masing penyebutan tokoh dengan benar, dan 1 poin apabila penyebutan tokoh tidak sesuai dengan 
cerita. Total nilai pada indikator ini adalah 14 poin. Penggunaan konjungsi dinilai apabila siswa mampu menggunakan konjungsi dengan tepat yang menghubungkan gagasan atau menghubungkan bagian-bagian penceritaan dengan total nilai 6 poin. Pembentukan kata-kata gramatikal ditentukan apabila siswa mampu menggunakan konjungsi dengan tepat yang menghubungkan gagasan atau menghubungkan bagian-bagian penceritaan dengan total nilai 6 poin. Selain itu, piranti-piranti naratif dinilai berdasarkan penggunaan kalimat langsung dan kalimat tak langsung, penyifatan pada tokoh, penggunaan keterangan untuk mendeskripsikan bagaimana kegiatan itu dilakukan, penyangatan terhadap objek cerita, gaya stilistik, dengan total nilai 4 poin.

Berkaitan dengan keterampilan kohesi naratif/referensial, hampir semua anak Tuli dapat memberikan atau menuliskan tokoh dalam cerita, akan tetapi semua tokoh tersebut tidak sesuai atau tidak menggambarkan tokoh yang dideskripsikan dalam film 'Kisah Buah Pir'. Dalam film tersebut terdapat tujuh kohesi referensial yaitu petani, buah pir, penggembala kambing, kambing, anak laki-laki yang mencuri buah pir, seorang gadis bersepeda, dan tiga orang anak laki-laki yang membantu anak laki-laki yang mencuri buah pir. Beberapa kohesi referensial yang disebutkan oleh anak Tuli dalam merujuk tokoh dalam kisah buah pir adalah sebagai berikut:

1. Petani diidentifikasi dengan sebutan Ayah, Bapak, saya, atau aku.

2. Buah pir diidentifikasi dengan sebutan buah jambu, mangga, pepaya, apel, atau alpukat.

3. Anak laki-laki yang mencuri buah pir diidentifikasi dengan sebutan anak laki-laki, aku, saya atau adik.

4. Gadis bersepeda diidentifikasi dengan sebutan ibu atau perempuan. Sebagian besar tidak dapat mengidentifikasi tokoh ini.

5. Tiga anak laki-laki diidentifikasi dengan sebutan anak-anak, kakak, atau adik.

6. Penggembala kambing diidentifikasi dengan sebutan Bapak, Kakak, atau Saya. Sebagian besar anak Tuli tidak mengidentifikasi tokoh ini.

7. Kambing diidentifikasikan sebagai kambing, sapi atau rusa.

Dalam hal penggunaan konjungsi, ditemukan bahwa tidak ada satu pun anak Tuli yang menggunakan konjungsi dalam tulisan mereka. Perhatikan data di bawah ini:

Pohon-Pohon Buahan-Buah Alpukat

(1) Ayah mengambil buahan-buah alpukat di pohon

'ayah mengambil buah alpukat di pohon'

Ayah memberi buahan-buah alpukat di tempat

'ayah memberi [menaruh] buah alpukat di tempat'

Anak-anak mencuri buahan-buah alpukat, anak-anak naik sepeda

'anak-anak mencuri buah alpukat, anak-anak menaiki sepeda'

$(\mathrm{ABF} / \mathrm{VI} / 16)$

Paragraph narasi yang terdapat dalam (1) di atas memiliki tiga kalimat tunggal dengan pemerian di bawahnya dengan tanda glos ('...') adalah upaya memberikan makna gramatikal yang tepat untuk membantu memahami makna yang disusun oleh anak Tuli. Selain itu, ada verba 'memberi' yang kemungkinan bermakna 'menaruh'. Hal ini jamak ditemui dalam karangan anak Tuli karena keterbatasan kosakata yang dimiliki, yaitu seringkali satu verba 
memiliki banyak makna dan digunakan dalam ragam konteks yang berbeda. Ketiga kalimat tunggal tersebut dimungkinkan untuk dirangkaikan dengan konjungsi 'dan' atau 'kemudian'.

Indikator kata-kata grammatikal dinilai dari banyaknya penggunaan verba utama yang berjumlah 15, yaitu memanen, memilih, membawa, membantu, menggembala, bersepeda, mencuri, mengayuh, melihat, menabrak, jatuh, berserakan, memunguti, memberikan, mengumpulkan, mengucapkan terimakasih, dan memakan. Dari penilaian diketahui bahwa nilai rata-rata anak Tuli adalah $2.3(17 \%)$ dari nilai maksimum 17 poin. Temuan yang layak diperhatikan dengan saksama adalah sebagai berikut:

1. Anak Tuli cenderung menggunakan verba yang terbatas yaitu membawa, membantu, melihat, mengambil, mencuri, memetik, menolong, jatuh, dan menculik.

2. Tidak ada anak Tuli yang menggunakan kata memanen, yang merupakan salah satu verba inti dalam cerita. Sebagai gantinya mereka menggunakan kata memetik dan mengambil.

3. Sebagian besar anak Tuli menggunakan kata mengambil dan membawa yang merujuk pada kata mencuri. Satu anak Tuli menggunakan kata menculik untuk mengartikan 'mencuri', dan hanya tiga anak Tuli yang menggunakan kata mencuri.

4. Anak Tuli menggunakan kata dasar tabrak untuk merujuk pada menabrak.

5. Sebagian anak Tuli menggunakan banyak kata dasar seperti tabrak, jatuh, naik, ambil, dan pergi.

Terkait penggunaan piranti-piranti naratif, hanya dua orang anak Tuli yang menggunakannya dalam bentuk komentar evaluasi, yaitu "Dasar anak-anak (terkait dengan kenakalan dalam mencuri" dan penggunaan piranti naratif dalam bentuk penyangatan dengan memberikan keterangan pada buah pir "Jambu jatuh kotor dan sangat kotor".

(1) Ibu sepeda jatuh buah jambu kotor (AAM/IV)

(2) Buah jambu jatuh kotor (AAA/IV)

Pada tingkat struktur mikro, ditemukan bahwa anak Tuli cenderung menggunakan kohesi referensial yang tidak sesuai dengan cerita. Dalam pengidentifikasian tokoh petani, anak Tuli cenderung menyebutnya dengan kata ganti bapak, ayah, kakak, atau aku, seperti contohcontoh di bawah ini.

(3) Ayah memetik pohon jambu banyak (AAK/IV)

(4) Bapak memetik buah manga di kebun buah-buahan (AHV/IV)

(5) $A k u$ memetik alpukat (DR/IV)

(6) Kakak mengambil papaya jalan pulang (R/II)

Hal ini dimungkinkan mengingat pengetahuan mereka tentang berbagai macam jenis karakter masih sangat lemah. Ini sejalan dengan penelitian sebelumnya, yaitu bahwa anak Tuli tidak memiliki skemata cerita yang memadai sehingga anak Tuli kesulitan dalam menyusun ulang cerita yang mereka dapatkan. Hal ini disebabkan karena anak Tuli dengan keterlambatan perkembangan bahasa cenderung mengalamai keterlambatan ToM (Theory of Mind) (Bernaix, 2013). ToM adalah kemampuan manusia terkait dengan pengambilan perspektif sehingga kemampuan ini dirasa penting dalam penguasaan keterampilan menulis narasi karena mempengaruhi perspektif kita dalam memandang atau memahami tokoh dalam sebuah cerita. 
Anak Tuli yang mengalami keterlambatan dalam perkembangan bahasanya cenderung mengalami keterlambatan ToM sehingga membuat mereka kesulitan dalam memahami karakter dalam sebuah cerita, siapakah karakter itu, apa yang dilakukan karakter itu, dan apa yang dirasakan karakter itu (Bernaix, 2013). Hal ini mengakibatkan mereka cenderung menggunakan perspektifnya sendiri dalam mengidentifikasi tokoh dalam sebuah cerita. Hal inilah yang melatarbelakangi penyebutan tokoh dengan kata ganti orang ketiga yang sangat dekat dengan kehidupan anak Tuli, yaitu Bapak, Ayah, Kakak dan Saya. Begitu pula penyebutan buah pir yang diidentifikasi dengan buah lokal yang sering mereka temui dalam kehidupan sehari-hari, seperti buah jambu, apel, mangga, alpukat dan papaya.

\section{SIMPULAN}

Keterampilan naratif memiliki peran penting dalam perkembangan bahasa seseorang termasuk anak Tuli. Lemahnya kemampuan naratif anak Tuli menunjukkan bahwa paparan dan intervensi penguasaan bahasa anak Tuli sangat kurang sehingga mempengaruhi keterampilan literasi mereka. Lemahnya kemampuan anak Tuli pada tingkat mikro (penguasaan kosakata dan konjungsi) berdampak pada kemampuan anak Tuli dalam memahami dan menyampaikan pesan. Kondisi ini tentu saja akan berdampak buruk bagi kemampuan akademis dan kemampuan komunikasi anak Tuli mengingat rendahnya kemampuan naratif juga mempengaruhi kemampuan persepsi anak Tuli terhadap dunia di sekitarnya sehingga persepsi referensial anak Tuli terhadap dunia sekitarnya menjadi terhambat.

\section{CATATAN}

* Penelitian ini didanai oleh Fakultas Ilmu Budaya, Universitas Brawijaya melalui program DPP SPP.

* Penulis berterima kasih kasih kepada mitra bebestari yang telah memberikan saran-saran untuk perbaikan makalah ini.

\section{DAFTAR PUSTAKA}

Bernaix, N. E. (2013). Oral and written narrative production in children who are deaf and hard of hearing, Tesis, Washington University School of Medicine.

Chamberlain, C., \& Mayberry, R. I. (2008). American Sign Language syntactic and narrative comprehension in skilled and less skilled readers: Bilingual and bimodal evidence for the linguistic basis of reading. Applied Psycholinguistics, 29(3), 367-388. https://doi.org/10.1017/S014271640808017X

Jones, -a. C., Toscano, E., Botting, N., Marshall, C.-R., Atkinson, J. R., Denmark, T., Morgan, G. (2016). Narrative skills in deaf children who use spoken English: Dissociations between macro and microstructural devices. Research in Developmental Disabilities, 59, 268-282. https://doi.org/10.1016/j.ridd.2016.09.010

Labov, W. (1972). Language in the inner city: Studies in the Black English vernacular. Philadelphia: University of Pennsylvania Press.

Negueruela, E. (2008). Revolutionary pedagogies: Learning that leads (to) second language development. In Sociocultural theory and the teaching of second languages (pp. 189227). London, England: Equinox. 
Pavlenko, A., \& Lantolf, J. P. (2000). Second language learning as participation and (re)construction of selves. In Sociocultural theory and second language learning (hlm. 155-77). Oxford, England: Oxford University Press.

Rathmann, C., Mann, W., \& Morgan, G. (2007). Narrative structure and narrative development in deaf children. Deafness \& Education International, 9(4), 187-196. https://doi.org/10.1002/dei.228

Schley, S., \& Albertini, J. (2005). Assessing the Writing of Deaf College Students: Reevaluating a Direct Assessment of Writing. Journal of Deaf Studies and Deaf Education, 10, 96-105. https://doi.org/10.1093/deafed/eni006

Sukamto, K. E., \& Purwo, B. K. (2016). Oral narrative and descriptive proficiency in bilingual children: A case study of Javanese-Indonesian children. Linguistik Indonesia, 34(1), 85100. https://doi.org/10.26499/li.v34i1.43

Verhoeven, S., \& Strömqvist, L. (2001). Narrative development in a multilingual context. Amsterdam, Netherlands: John Benjamins. 